\title{
Costs and Returns Structure in Bottle Gourd on the Contract Vis-a-Vis Non-Contract Farms in the Jaipur District of Rajasthan
}

\author{
Arjun Singh Rajput ${ }^{1^{*}}$, Vikalp Sharma ${ }^{2}$ and R.C. Sharma ${ }^{3}$ \\ ${ }^{1}$ M.Sc. Student, SKN Collage of Agriculture, Jobner, Jaipur, Rajasthan, India \\ ${ }^{2}$ Ph. D. Student, Department of Agril. Econ. \& Mgmt., RCA, MPUAT, Udaipur, Rajasthan, India \\ ${ }^{3}$ Retd. Prof. \& Head, Department of Agricultural Economics, SKNAU, Jobner, Jaipur, Rajasthan, India \\ "Corresponding author: arjnrjpt@gmail.com (ORCID ID: 0000-0002-1345-7718)
}

Received: $24-08-2020$

Revised: $21-11-2020$

Accepted: 04-12-2020

\begin{abstract}
The present investigation was undertaken with a view to studying the costs and returns structure by the contract and non-contract farmers under contract farming of bottle gourd. Primary data were collected for the agricultural year 2015-16. The cost concepts were used. The results of the study revealed that all types of incomes viz., gross income, family labour income, farm business income and net income were higher on the contract farms than on the non-contract farms. The net income per hectare from bottle gourd was 31.69 per cent higher on the contract farms as compared to the non-contract farms. The total costs were higher on contract farms than on non-contract farms. The net profit was higher on contract farms than on non-contract farms. Returns per rupee were higher on contract farms (₹ 1.82) than noncontract farms (₹1.69).
\end{abstract}

\section{Highlights}

(O In bottle gourd cultivation the net income per hectare and returns per rupee was higher on the contract farms than the non-contract farms.

Keywords: bottle gourd, contract farming, gross income, net income

This study was related to contract farming revealed that the farmer's favoured contract farming because it provided them with better prices, gave them reliable incomes, generated employment especially for women, introduced improved practices of farming and did away with relationship between the large and small producers. India with vegetable production of 146.55 million tons is the second largest producer of vegetables contributing $14 \%$ of world's vegetable production in 2017-18. With an area of 10.4 million hectares under vegetables, the average productivity of vegetables in India was $17.3 \mathrm{t} / \mathrm{ha}$ in 2017-18. In Rajasthan 1.7 million ha area was under vegetable cultivation in 2017-18 with production of 17.675 tons and productivity of
6.3 t/ha. (Vegetable Statistics - IIVR (2017-2018). In Jaipur district Bassi, Jhotwara and Shahpura were the major blocks for the production of bottle gourd with an area and production of 125 hectares $(360 \mathrm{qt} /$ ha), 65 hectares (350qt/ha) and 50 hectares (350qt/ ha), respectively.

Productivity in agriculture can be increased through adoption of improved technology. Judicious use of resources coupled with proper technology plays an important role in stepping up agricultural production (Singh et al. 2006). It was

How to cite this article: Rajput, A.S., Sharma, V. and Sharma, R.C. (2020). Costs and Returns Structure in Bottle Gourd on the Contract Vis-a-Vis Non-Contract Farms in the Jaipur District of Rajasthan. Economic Affairs, 65(4): 665-674.

Source of Support: None; Conflict of Interest: None 
generally noticed that the farmers were not using recommended level of crop production technology. This results in a gap between the potential and actual yield. In the production of bottle gourd, farmers and contracting firms face many problems like transfer of technology, supply of quality seed, arrangements of institutional credit, fertilizers and other inputs, market arrangements, timely payments, violation of terms and conditions, lack of proper management by the company, frequent price fluctuations in markets, lack of transport facilities during peak periods, etc.

Examination of costs and returns in agriculture plays a significant role in making the farm sector economically viable and feasible under the pressure of continuous rise in input prices (Kale et al. 2005). The level of input use and their prices affect the profitability of the crop enterprise. This mechanism needs to be critically examined for formulating effective policies in relation to costs and output prices for understanding the income path in the farm sector. As such there was a need to study the costs of and returns on different size-groups of contract and non-contract farms in the Jaipur district.

\section{DATABASE AND METHODOLOGY}

In Jaipur district contract farming in case of cucurbits was prevalent only in three tehsils namely Bassi, Jhotwara and Shahpura. Among these three tehsils, Bassi tehsil ranks first in area and production of bottle gourd. Therefore, bassi tehsil was selected purposively for the study purpose. Multi stage stratified random sampling technique was used for drawing a sample for the present study. A list of 26 villages having contract farming in bottle gourd was obtained from the Bassi tehsil. Three villages namely Dhindon, Damodarpura and Kacholiya were selected randomly. Out of 127 bottle gourd growers (57 were contract farmers and 70 were non-contract farmers), 50 farmers were selected randomly for the study of which, 30 were contract and 20 were non-contract farmers.

The costs and returns of bottle gourd were analyzed for the contract and non-contract farmers to examine the economics of crop production. The cost concepts used for estimating costs, gross returns and net returns in respect of bottle gourd crop are given below:

\section{Cost concepts}

Costs were computed by following certain cost concepts and items of costs (all measured in monetary terms) as discussed below:

\section{Cost $A_{1}$ :}

(i) Value of hired human labour

(ii) Value of hired bullock labour

(iii) Value of owned bullock labour

(iv) Value of owned machinery

(v) Hired machinery charges

(vi) Value of seed (both farm produced and purchased)

(vii) Value of manures (both farm produced and purchased)

(viii) Value of fertilizers

(ix) Value of insecticides and pesticides

(x) Irrigation charges

(xi) Depreciation on farm buildings and implements

(xii) Interest on working capital

(xiii) Insurance premium

(xiv) Land revenue

(xv) Miscellaneous expenses

Cost $\mathbf{A}_{2}:$ Cost $A_{1}+$ rent paid for leased-in land

Cost $\mathbf{B}_{1}$ : Cost $A_{1}+$ interest on fixed capital (excluding land)

Cost $\mathbf{B}_{2}$ : Cost $B_{1}+$ rental value of owned land + rent paid for leased-in land

Cost $C_{1}$ : Cost $B_{1}+$ imputed value of family labour

Cost $C_{2}$ : Cost $B_{2}+$ imputed value of family labour

Cost $C_{3}:$ Cost $C_{2}+10$ per cent of cost $C_{2}$ as management cost

\section{Rental value of owned land}

It was calculated on the basis of prevailing rates in the sample villages i.e., ₹ 10000 per year.

Depreciation: Depreciation on an asset was calculated using the straight line method:

Depreciation $=\frac{\text { Purchase price of an asset }- \text { Junk value }}{\text { Expected life of the asset in years }}$ 
Depreciation for crop $=$

$$
\frac{\text { Total annual depreciation }}{\text { Total cropped area }} \times \text { Area under crop }
$$

Cost of production (per quintal) - Cost of production was worked out by using following formula:

Cost of production per quintal $=\frac{\text { Total Cost }\left(\operatorname{Cost~} \mathrm{C}_{2}\right) / \text { ha }}{\text { Yield } / \text { ha }}$

Operational cost (O.C.) - It is the variable cost that varies with the level of production. It was expressed as:

$O C=$ Cost $A_{1}-$ Land revenue - Depreciation + Family labour charges

\section{Overhead cost (O.H.C.)}

Overhead cost or fixed costs were the sunk costs which had no bearing on the size of production. These were calculated by subtracting variable costs from the $\operatorname{cost} C_{2}$. In other words,

$$
\mathrm{OHC}=\operatorname{Cost} \mathrm{C}_{2}-\text { Variable costs }
$$

\section{Gross income}

Synonymous with value of output (both main product and by-product) evaluated at harvest prices. Symbolically:

$$
G I=Q_{m} \times P_{m}+Q_{b} \times P_{b}
$$

where,

$G I=$ Gross Income; $Q_{m}=$ Quantity of main product; $P_{m}=$ Price of main product; $Q_{b}=$ Quantity of byproduct; $P_{b}=$ Price of by-product

Family labour income (FLI) - It is the return to family labour (including management).

\section{Net income (NI)}

$$
N I=\text { Gross income }- \text { Total cost }\left(\operatorname{Cost} C_{2}\right)
$$

Farm business income (FBI) - It is the disposal income out of the enterprise and is defined as:

FBI $=$ Gross income - Cost $A_{1}\left(\right.$ cost $A_{2}$ in case of tenant operated land)

\section{Return per rupee (RPR)}

$$
R P R=\frac{\text { Gross Income } / \text { ha }}{\text { Total Cost }\left(\text { Cost } \mathrm{C}_{2}\right) / \text { ha }}
$$

\section{RESULTS AND DISCUSSION}

\section{Costs and returns structure}

This sub section deals with the economics of bottle gourd crop production during zaid based on utilization of farm inputs.

\section{Utilization of farm inputs in physical quantity in bottle gourd on contract farms}

The table 1 indicates that the utilization of machine labour varied from $406.33 \mathrm{hrs} / \mathrm{ha}$ on small farms to $420.52 \mathrm{hrs} / \mathrm{ha}$ on large farms. Overall machine labour utilization was $412.31 \mathrm{hrs} / \mathrm{ha}$. Utilization of total human labour was highest (85.17 man days/ ha) on small farms and lowest (81.94 man days/ha) on large farms. Overall utilization of human labour was estimated at 83.04 man days/ha which was more than that utilized on medium and large farms.

\section{Utilization of farm inputs in physical quantity in bottle gourd on non- contract farms}

The table 2 indicates that the utilization of machine labour was highest (385.98 hrs/ha) on large farms followed by medium (382.09 hrs/ha) and small (373.98 hrs/ha) farms. Overall machine labour utilization was $380.67 \mathrm{hrs} / \mathrm{ha}$.

Utilization of family labour varied from 21.30 man days/ha on large farms to 64.20 man days/ha on small farms with an overall family labour utilization of 40.17 man days/ha. Utilization of hired human labour varied from 17.01 man days/ha on small farms to 54.10 man days/ha on large farms with an overall hired labour utilization of 38.23 man days/ha. Utilization of family labour was inversely related with hired human labour. It decreased with the increase in size of farms. In case of hired human labour the trend was just reverse. Utilization of total human labour varied from 75.40 man days/ha on large farms to 81.21 man days/ha on small farms with an overall human labour utilization of 78.41 man days/ha in the study area. Lesser utilization of human labour on large farms was attributable to more use of machine labour on such farms.

Utilization of farm inputs in monetary terms in bottle gourd on contract farms

The table 3 indicates that on contract farms, miscellaneous expenses occupied a lion's share 
Table 1: Utilization of farm inputs in physical quantity on contract farms (2015-16)

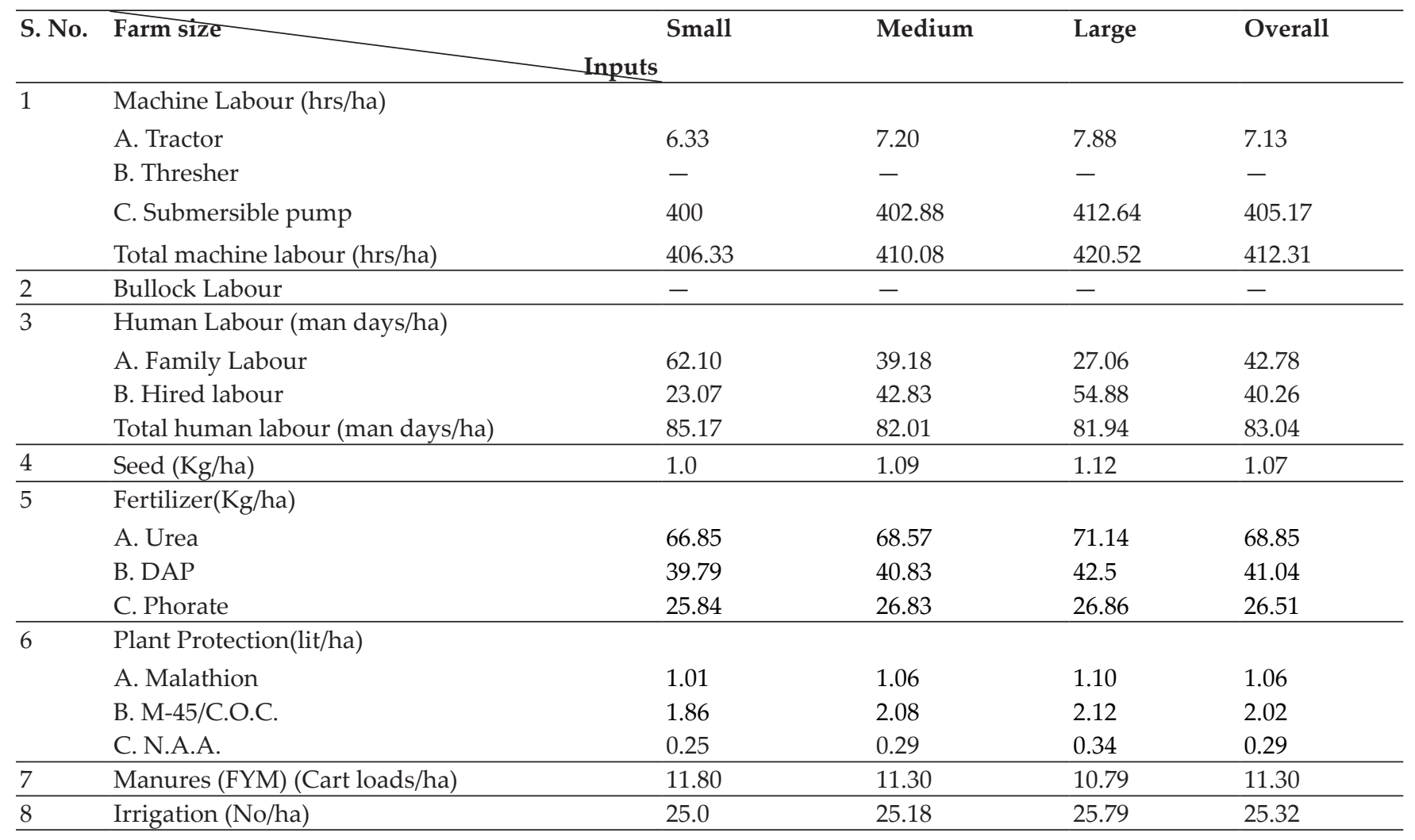

Table 2: Utilization of farm inputs in physical quantity in bottle gourd on non-contract farms (2015-16)

\begin{tabular}{|c|c|c|c|c|c|}
\hline S1. No. & Inputs & Small & Medium & Large & Overall \\
\hline \multirow[t]{5}{*}{1} & Machine Labour (hrs/ha) & & & & \\
\hline & A. Tractor & 5.98 & 6.89 & 7.10 & 6.65 \\
\hline & B. Thresher & - & - & - & - \\
\hline & C. Submersible pump & 368 & 375.20 & 378.88 & 374.02 \\
\hline & Total machine labour (hrs/ha) & 373.98 & 382.09 & 385.98 & 380.67 \\
\hline 2 & Bullock Labour & - & - & - & - \\
\hline \multirow[t]{4}{*}{3} & Human Labour (man days/ha) & & & & \\
\hline & A. Family Labour & 64.20 & 35.02 & 21.30 & 40.17 \\
\hline & B. Hired labour & 17.01 & 43.60 & 54.10 & 38.23 \\
\hline & Total human labour (man days/ha) & 81.21 & 78.62 & 75.40 & 78.41 \\
\hline 4 & Seed $(\mathrm{Kg} / \mathrm{ha})$ & 0.98 & 1.10 & 1.08 & 1.03 \\
\hline \multirow[t]{4}{*}{5} & Fertilizer (Kg/ha) & & & & \\
\hline & A. Urea & 50 & 54.28 & 59.28 & 54.52 \\
\hline & B. DAP & 36.45 & 40 & 43.75 & 40.06 \\
\hline & C. Phorate & 21.75 & 22.62 & 23.59 & 22.65 \\
\hline \multirow[t]{4}{*}{6} & Plant Protection (lit/ha) & & & & \\
\hline & A. Malathion & 0.90 & 1.0 & 1.05 & 0.98 \\
\hline & B. M-45/C.O.C. & 1.56 & 1.96 & 2.08 & 1.87 \\
\hline & C. N.A.A. & 0.22 & 0.25 & 0.32 & 0.26 \\
\hline 7 & Manures (Cart loads/ha) & 9.18 & 8.15 & 7.71 & 8.35 \\
\hline 8 & Irrigation (No/ha) & 23.0 & 23.45 & 23.68 & 23.38 \\
\hline
\end{tabular}


Table 3: Utilization of farm inputs in monetary terms on contract farms (2015-16) (₹/ha)

\begin{tabular}{|c|c|c|c|c|c|}
\hline S1. No. & Farm size & Small & Medium & Large & Overall \\
\hline 1 & Rental value of land & $10000(11.53)$ & $10000(11.02)$ & $10000(10.47)$ & $10000(10.99)$ \\
\hline \multirow[t]{4}{*}{3} & Machine labour & & & & \\
\hline & A. Owned & $820(0.95)$ & $1580(1.74)$ & $2456(2.57)$ & $1618.67(1.78)$ \\
\hline & B. Hired & $2780(3.20)$ & $2200.33(2.43)$ & $1514.07(1.59)$ & $2164.8(2.38)$ \\
\hline & C. Total & $3600(4.15)$ & $3780.33(4.17)$ & $3970.07(4.16)$ & $3783.46(4.16)$ \\
\hline 4 & Irrigation charge & $6250(7.21)$ & $6500(7.17)$ & $6720(7.04)$ & $6490(7.13)$ \\
\hline \multirow[t]{4}{*}{5} & Human labour & & & & \\
\hline & A. Family labour & $15525(17.90)$ & $9795(10.80)$ & $6765(7.09)$ & $10695(11.76)$ \\
\hline & B. Hired labour & $5767.5(6.65)$ & $10707.5(11.80)$ & $13720(14.37)$ & $10065(11.06)$ \\
\hline & C. Total & $21292.5(24.55)$ & $20502.5(22.60)$ & $20485(21.45)$ & $20760(22.82)$ \\
\hline 6 & Seed & $3800(4.38)$ & $4143.33(4.57)$ & $4207.40(4.41)$ & $4050.24(4.45)$ \\
\hline \multirow[t]{5}{*}{7} & Fertilizer & & & & \\
\hline & A. Urea & $468(0.54)$ & $480(0.53)$ & $498(0.52)$ & $482(0.53)$ \\
\hline & B. DAP & $955(1.10)$ & $980(1.08)$ & $1020(1.07)$ & $985(1 . .08)$ \\
\hline & C. Phorate & $2584(2.98)$ & $2653.33(2.93)$ & $2686.52(2.81)$ & $2641.28(2.90)$ \\
\hline & D. Total & $4007(4.62)$ & $4113.33(4.53)$ & $4204.52(4.40)$ & $4108.28(4.52)$ \\
\hline \multirow[t]{5}{*}{8} & Plant protection & & & & \\
\hline & A. Malathion & $353.5(0.41)$ & $371(0.41)$ & $385(0.40)$ & $369.83(0.41)$ \\
\hline & B. M-45/C.O.C. & $595.2(0.69)$ & $665.6(0.73)$ & $678.4(0.71)$ & $646.4(0.71)$ \\
\hline & C. N.A.A. & $350(0.40)$ & $406(0.45)$ & $476(0.50)$ & $411(0.45)$ \\
\hline & D. Total & $1298.7(1.50)$ & $1442.6(1.59)$ & $1539.4(1.61)$ & $1427.23(1.57)$ \\
\hline 9 & Manure (FYM) & $9446.67(10.89)$ & $9043.93(9.97)$ & $8635.3(9.04)$ & $9041.96(9.94)$ \\
\hline 10 & Land revenue & $27(0.03)$ & $27(0.03)$ & $27(0.03)$ & $27(0.03)$ \\
\hline 11 & Depreciation & $206.55(0.24)$ & $302.57(0 . .33)$ & $419.85(0 . .44)$ & $309.65(0.34)$ \\
\hline 12 & Interest on working capital & $597.97(0.69)$ & $629.14(0.69)$ & $752.44(0.79)$ & $659.85(0.73)$ \\
\hline 13 & Interest on fixed capital & $426.11(0.49)$ & $540.13(0.60)$ & $647.13(0.68)$ & $537.79(0.59)$ \\
\hline 14 & Miscellaneous expenses & 25791.07 (29.73) & $29686.50(32.73)$ & 33874.55 (35.48) & $29784.04(32.74)$ \\
\hline 15 & Total & $86743.57(100)$ & $90711.36(100)$ & $95482.66(100)$ & $90979.51(100)$ \\
\hline
\end{tabular}

Figures in parentheses are percentages by the total.

(32.74 per cent) in the total cost of cultivation for bottle gourd (₹ 90979.51). The next major component of cost was irrigation charges which accounted for 7.13 per cent of the total cost. The irrigation charges increased with small farms (₹ 6250) to the large farms (₹ 6720). The family labour charges were higher $₹ 15525$ on small farms as compared to that on large farms (₹ 6765) - overall charges being $₹ 10695$ per hectare.

\section{Utilization of farm inputs in monetary terms in} bottle gourd on non- contract farms

The table 4 indicates that the rental value of land ( $₹$ $10000)$ occupied (12.16 per cent) share in the total cost of cultivation ( $₹$ 82220.40). Irrigation charges with 7.40 per cent followed by human labour (23.84 per cent), manure (8.12) and miscellaneous expenses
(29.55) stood next as major cost components. Family labour and hired human labour charges inversely varied with the size of holding. Per hectare expenditure on human labour decreased with the increase in the size of farms in the study area.

Fertilizer cost increased with the increase in size of farms due to lesser availability of manures on large farms. Interest on working capital and fixed capital jointly accounted for 1.65 per cent of the total cost.

\section{Comparative economics of bottle gourd cultivation on contract and non-contract farms}

The table 5 indicates that overall costs $\mathrm{A}_{1^{\prime}}, \mathrm{A}_{2^{\prime}}$ $\mathrm{B}_{1}, \mathrm{~B}_{2}, \mathrm{C}_{1}$ and $\mathrm{C}_{2}$ on contract farms were worked out at ₹ 69746.74, ₹ 79746.41, ₹ 70284.53, ₹ $80284.53 ₹ 80979.20$ and $₹ 90979.20$, respectively. These respective costs were higher by ₹ 8336.06, 
Table 4: Utilization of farm inputs in monetary terms on non- contract farms (2015-16) (₹/ha)

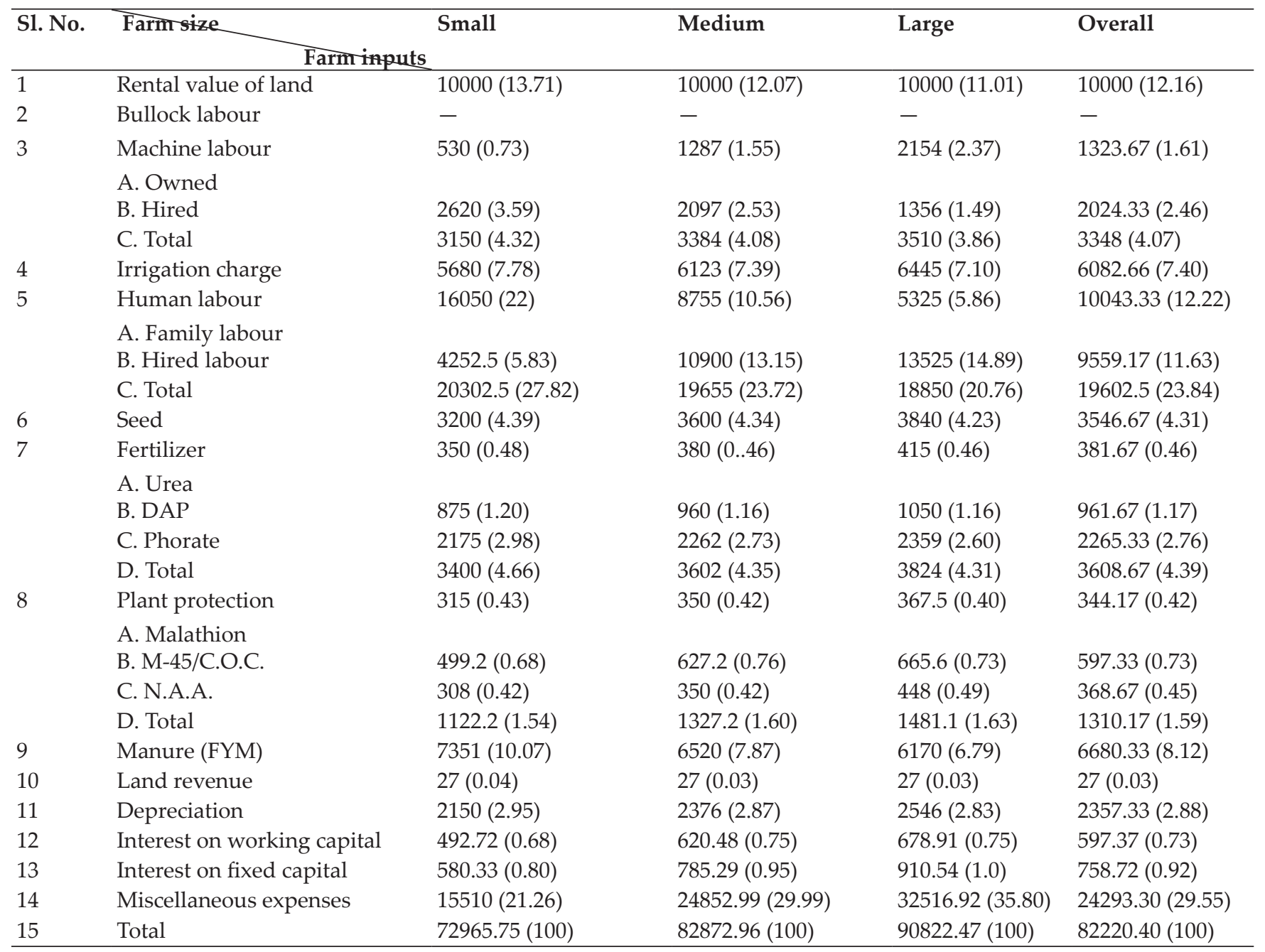

Figures in parentheses are percentages by the total.

Table 5: Comparative economics on contract and non-contract farms (2015-16) (₹/ha)

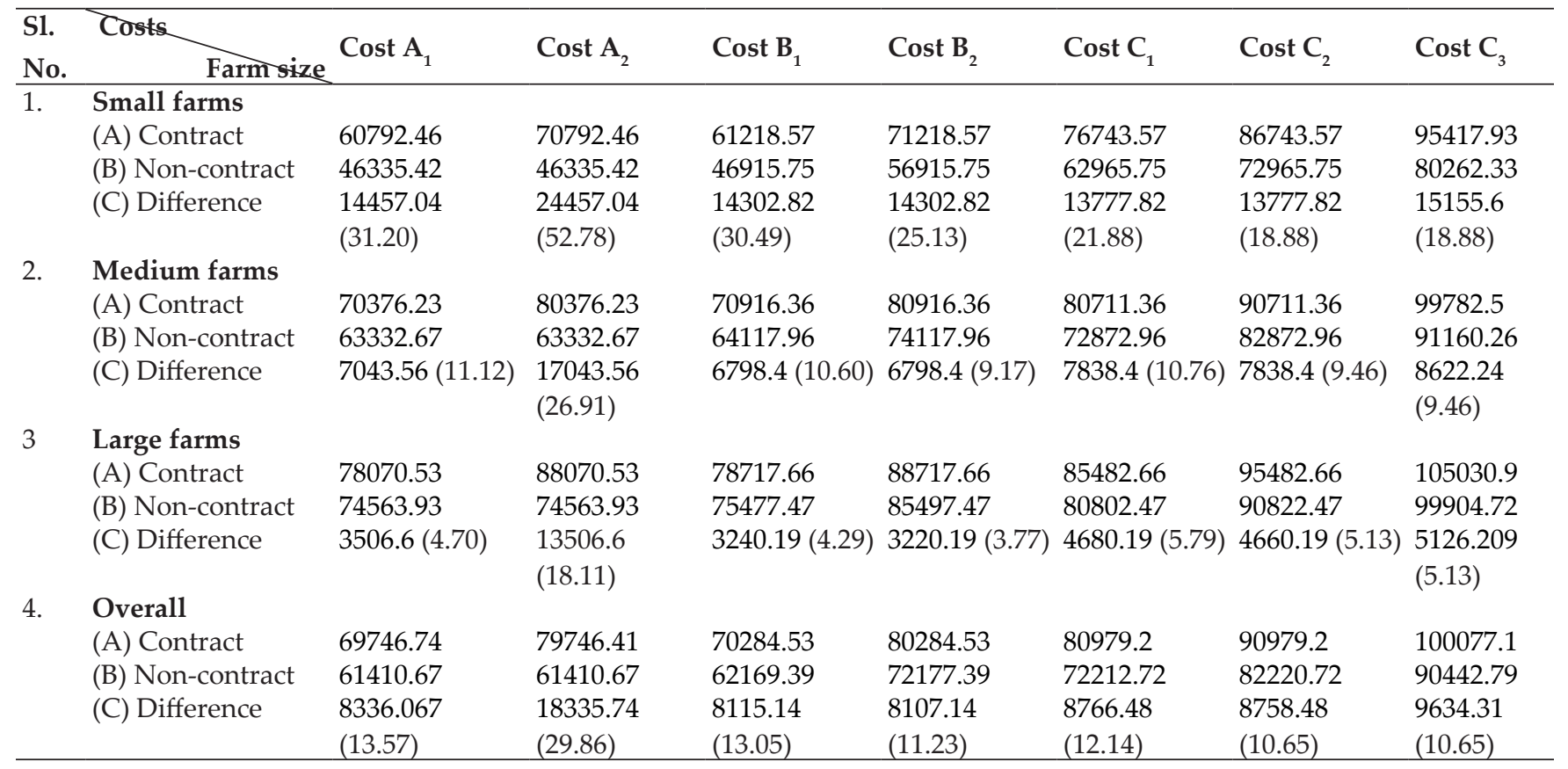


₹ 18335.74, ₹ 8115.14, ₹ 8107.14, 8766.48 and ₹ 8758.48 on contract farms than on non-contract farms. Cost $A_{2}$ was more than to cost $A_{1}$ as farmers of the contract farms had leased in land. Magnitude of cost $C_{2}$ was $₹ 86743.57$ on small farms of contract farms as against $₹ 72965.75$ on non-contract small farms.

The difference of cost $\mathrm{C}_{2}$ was more on non-contract farms (₹ 125981.21) than contract farms (₹ 105769.50). These costs increase with increased of size of holdings. These results were in confirmity with Dileep et al. (2002), Singh et al. (2006) and Kumar et al. (2019).

The variation in all the cost concepts on contract and non-contract farms was due to the variation in the input use and investments made in farm assets by the selected contract and non-contract farms. These findings were in confirmity with Dileep et al. (2002), Tripathi et al. (2005) and Singh et al. (2006). The cost differences between contract and non-contract farms were observed higher on small farms followed by medium and large farms because of less investment and low risk bearing capacity of the non-contract farms in respective categories.

\section{Net profit from the cultivation of bottle gourd on contract and non- contract farms}

The table 6 indicates that overall gross returns, total Costs and net profit on contract farms were worked out at ₹ 165191.38, ₹ 90979.20 and ₹ 74212.18 per hectare, respectively. These parameters were higher by ₹ 26618.12 (19.21 per cent), ₹ 8758.48 (10.65 per cent) and ₹ 17859.64 (31.69 per cent) than on noncontract farms.

The overall gross return was higher on contract farms (₹ 165191.38) than the non-contract farms (₹ 138573.26). The total costs incurred on cultivation of bottle gourd were higher on contract farms than on non-contract farms. The total cost of cultivation on contract farms was higher due to more use of farm inputs than on non-contract farms.

The net profit was higher on contract farms (₹ 74212.18) than on non-contract farms ( $₹$ 56352.54). This was attributable to realization on higher price and more physical output than on non-contract farms. These results were in confirmity with Singh et al. (2006) and Sivagami et al. (2010).

\section{Family labour income, farm business income and returns per rupee from the cultivation of Bottle gourd on contract and non- contract farms}

The table 7 indicates that overall family labour income, farm business income and returns per rupee on contract farms were worked out at ₹ 84906.85, ₹ 95444.64 and $₹ 1.82$ per hectare, respectively. These parameters were higher by ₹ 18510.98 (27.88 per cent), ₹ 18282.05 (23.69 per cent) and ₹ 0.13 (7.73 per cent) than on non-contract farms.

Category wise family labour income varied from

Table 6: Net profit on contract and non-contract farms (2015-16) (₹/ha)

\begin{tabular}{lllll}
\hline Sl. No. & Farm size & Gross return & Total cost & Net profit \\
\hline 1 & Small farms & & & \\
& (A) Contract & 153230.58 & 86743.57 & 66487.01 \\
(B) Non-contract & 121000.00 & 72965.75 & 48034.25 \\
(C) Difference & $32230.58(26.64)$ & $13777.82(18.88)$ & $18452.76(38.42)$ \\
2 & & & \\
& Medium farms & 165530.23 & 90711.36 & 74818.87 \\
(A) Contract & 139740.89 & 82872.96 & 56867.93 \\
(B) Non-contract & $25789.34(18.46)$ & $7838.40(9.46)$ & $17950.94(31.57)$ \\
(C) Difference & & & \\
3 & Large farms & 176813.33 & 95412.66 & 81330.67 \\
(A) Contract & 154978.89 & 90822.47 & 64156.42 \\
(B) Non-contract & $21834.44(14.09)$ & $4660.19(5.13)$ & $17174.25(26.77)$ \\
(C) Difference & & & \\
Overall & 165191.38 & 90979.20 & 74212.18 \\
(A) Contract & 138573.26 & 82220.72 & 56352.54 \\
(B) Non-contract & $26618.12(19.21)$ & $8758.477(10.65)$ & $17859.64(31.69)$ \\
\hline
\end{tabular}


$\underset{\text { AESSRA }}{\sqrt{U}}$ Rajput et al.

Table 7: Family labour income, farm business income and return per rupee on contract and non-contract farms (2015-16) (₹/ha)

\begin{tabular}{|c|c|c|c|c|}
\hline Sl. No. & Farm size & Family labour income & Farm business income & Return per rupee \\
\hline \multirow[t]{4}{*}{1} & Small farms & & & \\
\hline & (A) Contract & 82012.01 & 92438.12 & 1.77 \\
\hline & (B) Non-contract & 64084.25 & 74664.58 & 1.66 \\
\hline & (C) Difference & $17927.76(27.98)$ & $17773.54(23.80)$ & $0.11(6.52)$ \\
\hline \multirow[t]{3}{*}{2} & Medium farms & & & \\
\hline & (A) Contract & 84613.87 & 95154 & 1.82 \\
\hline & (C) Difference & $18990.94(28.94)$ & $18745.78(24.53)$ & $0.13(8.22)$ \\
\hline \multirow[t]{4}{*}{3} & Large farms & & & \\
\hline & (A) Contract & 88095.67 & 98742.80 & 1.85 \\
\hline & (B) Non-contract & 69481.42 & 80414.96 & 1.71 \\
\hline & (C) Difference & $18614.25(26.79)$ & $18327.84(22.79)$ & $0.14(8.52)$ \\
\hline 4 & (C) Difference & $18510.98(27.88)$ & $18282.05(23.69)$ & $0.13(7.73)$ \\
\hline
\end{tabular}

Table 8: Operational cost, overhead cost and cost of production on contract and non-contract farms (2015-16)

\begin{tabular}{lllll}
\hline S1. No. & Farm size & $\begin{array}{l}\text { Operational cost } \\
\text { (₹/ha) }\end{array}$ & $\begin{array}{l}\text { Overhead cost } \\
\text { (₹/ha) }\end{array}$ & $\begin{array}{l}\text { Cost of production } \\
\text { (₹/q) }\end{array}$ \\
\hline 1 & Small farms & & & 294.94 \\
(A) Contract & 76083.91 & 52573.70 & 348.19 \\
(B) Non-contract & 60208.42 & 44810.05 & -53.25 \\
(C) Difference & $15875.49(26.37)$ & $7763.65(13.33)$ & 304.82 \\
Medium farms & & & 379.16 \\
(A) Contract & 79841.66 & 50980.34 & -74.34 \\
(B) Non-contract & 69684.67 & 47416.76 & 316.87 \\
(C) Difference & $10156.99(14.58)$ & $3563.58(7.52)$ & 412.83 \\
Large farms & & & -95.96 \\
(A) Contract & 84388.68 & 52485.97 & 52027.37 \\
(B) Non-contract & 77315.93 & $458.6(0.88)$ & 305.63 \\
(C) Difference & $7072.75(9.15)$ & & 380.58 \\
Overall & & 52013.01 & -74.94 \\
(A) Contract & 80105.08 & 48085.05 & $3927.96(8.17)$ \\
(B) Non-contract & 69069.67 & $11035.41(15.98)$ & \\
(C) Difference &
\end{tabular}

₹ 82012.01 on small farms to ₹ 88095.67 on large farms under contract farms and from ₹ 64084.25 to ₹ 69481.42 on non-contract farms. Similarly farm business income ranged from ₹ 92438.12 on small farms to ₹ 98742.80 on large farms under contract farms and from ₹ 74664.58 to ₹ 80414.96 on noncontract farms. Returns per rupee ranged from ₹ 1.77 on small farms to ₹ 1.85 on large farms under contract farms and from ₹ 1.66 to $₹ 1.71$ on the same categories of non-contract farms. Returns per rupee was higher on contract farms (₹ 1.82) than non- contract farms (₹ 1.69). The family labour income, farm business income and returns per rupee were higher on contract farms due to higher production and price of the product. These findings were in confirmity with Singh et al. (2006).

\section{Operational cost, overhead cost and cost of production from the cultivation of bottle gourd on contract and non- contract farms (2015-16)}

The table 8 indicates that overall operational cost, overhead cost and cost of production on contract 
farms were worked out at ₹ 80105.08, ₹ 52013.01 and ₹ 305.63 per hectare, respectively. These parameters were higher by ₹ 11035.41 (15.98 per cent), ₹ 3927.96 (8.17 per cent) and ₹ -74.94 than on non-contract farms.

Cost of production ranged from ₹ 316.87 on large farms to ₹ 294.94 on small farms under contract farms and from ₹ 412.83 to $₹ 348.19$ on the same categories of non-contract farms. Category wise difference in cost of production between contract and non-contract farms was higher on small farms followed by medium and large farms. The operational cost and overhead cost were higher on contract farms than on non-contract farms due to more use of inputs. It increased with the increase in the farm size. These findings were in conformity with Singh et al. (2006) and Singh et al. (2020). The cost of production was noted to be higher on noncontract farms. It may be attributed to less use of inputs, low output and less price of the output on these farms as compared to that on contract farms.

\section{CONCLUSION}

1. The utilization of human labour was highest on small farms and lowest on large farms. Utilization of machine labour was highest on large farms and lowest on small farms indication that machine labour replaced human labour with the increase in size of the farm.

2. The overall costs of cultivation of bottle gourd on contract and non-contract farms were estimated at $₹ 90979.51$ and $₹ 82220.40$ per hectare, respectively. The variation in all the cost concepts on contract and non-contract farms was due to the variation in the input use and investments made in farm assets by the selected contract and non-contract farms.

3. All types of cost concepts viz., costs $\mathrm{A}_{1^{\prime}} \mathrm{A}_{2^{\prime}}$ $\mathrm{B}_{1^{\prime}}, \mathrm{B}_{2^{\prime}}, \mathrm{C}_{1}, \mathrm{C}_{2}$ and $\mathrm{C}_{3}$ were higher on contract farms than on the non-contract farms. The reason being that the contract farmers invested more on hired human labour, machine labour, seeds, irrigation, manures, fertilizers and plant protection chemicals.

4. The operational cost and overhead cost were estimated to be 15.98 per cent and 8.17 per cent higher on contract farms as compared to that on non-contract farms due to more use of inputs. It increased with the increase in the farm size.

5. All types of farm incomes viz., gross income, family labour income, farm business income, returns per rupee and net income were higher on contract farms than on the noncontract farms.

6. The net income per hectare of bottle gourd was 31.69 per cent higher on the contract farms as compared to the non-contract farms. This was attributable to higher price and more physical output than realized on noncontract farms.

\section{Additional Comments}

- The government should make adequate arrangement for timely supply of necessary inputs at reasonable prices to the growers so as to increase per hectare productivity as well as net returns.

- Bank credit and financial assistance should be available to the individual farmers for increasing the production.

- Training of farmers in the areas of production technology, grading, standardization of produce, quality control and modern method of marketing will prove to be a viable move.

- The government should establish adequate storages at village level for the purpose of orderly marketing of bottle gourd to benefit both consumers and producers.

- This study was helped the farmers in reducing the cost of cultivation by using appropriate techniques and tools and improve the net return of the farmers in the study area.

\section{ACKNOWLEDGMENTS}

This research paper is part of my MSc. research work at SKNAU, Jobner, Jaipur so I thankful to My Major Advisor Dr. R.C. Sharma and my advisor committee who help and support me for my research work.

\section{REFERENCES}

Anonymous, 2017-18. Economic Survey. Vegetable Statistics - IIVR 
$\underset{\text { AESSRA }}{\mathbb{U}_{S}}$ Rajput et al.

Anonymous, 2017-18. Vital Agricultural Statistics. Directorate of Economics and Statistic, Jaipur.

Dileep, B.K., Grover, R.K. and Rai, K.N. 2002. Contract Farming of Tomato: An Economic Analysis. Indian Journal of Agricultural Economics, 57(2): 197-210.

Kale, N.K., Navadkar, D.S. Gavli, A.V. and Sale, D.L. 2005. Resource Use Efficiency in Chilli Cultivation in Thane District of Konkon Region. Indian Journal of Agricultural Economics, 60(3): 529.

Kumar, R., Kumar, N., Dhillon, A., Bishnoi, D.K., Kavita and Malik, A.K. 2019. Economic analysis of guava in Sonepat district of Haryana. Economic Affairs, 64(4): 747-752.

Singh, B., Singh, R.K. and Gupta, R.K. 2006. Contract Farming in Potato Production (An Alternative of Rural Marketing) in District of Farrukhabad, Uttar Pradesh. Indian Journal of Agricultural Marketing, 20(3): 57.
Singh, H., Kaur, M. and Sekhon, M.K. 2006. Contract Farming in Punjab-A Strategy for Diversification. Indian Journal of Agricultural Marketing, 20(3): 40-41.

Singh, N., Sharma, R. and Kayastha, R. 2020. Economic analysis of pea in Himachal Pradesh. Economic Affairs, 65(2): 191-195.

Sivagami, R., Alagumani, T. and Samsai, T. 2010. Integration of Production and Marketing of Maize through Contract Farming- An Economic Analysis. Indian Journal of Agricultural Marketing, 24(2): 145-151.

Tripathi, R.S., Singh, R. and Singh, S. 2005. Contract Farming in Potato Production: An Alternative for Managing Risk and Uncertainty. Agricultural Economics Research Review, (Conference No. 18): 47-60. 